\title{
NUMERICAL ANALYSIS OF INITIAL IMPERFECTION INFLUENCE ON THE PERFORMANCE OF BUCKLING-RESTRAINED BRACE
}

\author{
Ziqin Jiang, Yanlin Guo, Hang Chen, Xuqiao Zhang
}

Original scientific paper The interaction between the core and external restraining members of the buckling-restrained brace (BRB) should be considered because of the significant effect it may cause on the overall performance of BRBs. The mechanism of core member multi-wave deformation is studied for the first time in this research, which presents an actual flexural wave-shape development of core member with increasing axial load and reveals the contact force distribution and development between the core and external restraining members by employing the refined finite element (FE) analysis. The object-oriented programming language Python is applied in the ABAQUS parameter analysis, and the influences of initial imperfection of the core and external restraining members, as well as that of the gap amplitude, on BRB performance are also investigated. Numerical simulation results show that the reverse bending of core member triggered sudden buckling in high-order modes, as well as the overall stress decrease in the external restraining member, whereas the local stress increased with the development of the core deformation waveform. The BRB with the core of symmetric initial imperfection performed worse than that with the core of anti-symmetric initial imperfection in compression. Furthermore, less initial deflection of external restraining members and gap amplitude leads to smaller contact force, thus the BRB can perform more effectively.

Keywords: buckling-restrained brace; contact force distribution; gap; initial imperfection; refined finite element

\section{Numerička analiza utjecaja početne nesavršenosti na performansu spojnice ograničenog izvijanja}

Izvorni znanstveni članak

Potrebno je razmotriti interakciju između jezgre i vanjskih ograničavajućih elemenata kod spojnice ograničenog izvijanja (buckling-restrained brace BRB) zbog značajnog učinka na ukupnu performansu spojnica. Mehanizam deformacije elementa jezgre u obliku nekoliko valova, po prvi se puta analizira u ovom istraživanju i predstavlja element jezgre kao savojni valoviti oblik s povećavajućim aksijalnim opterećenjem te pokazuje distribuciju 1 razvoj dodirne sile između vanjskih i ograničavajućih elemenata jezgre analizom konačnih elemenata. Objektno orijentiran programski jezik Python primijenjen je u ABAQUS parametrijskoj analizi, a također se analiziraju utjecaji inicijalne nesavršenosti jezgre $i$ vanjskih elemenata ograničenja kao $i$ amplitude razmaka na performansu BRB. Rezultati numeričke simulacije pokazuju da je povratno savijanje elementa jezgre rezultiralo iznenadnim izvijanjem kod viših tipova oscilacije kao i sveukupno smanjenje naprezanja u vanjskom ograničavajućem elementu, dok je lokalno naprezanje poraslo $s$ razvojem valovitog oblika deformacije jezgre. Spojnica (BRB) s jezgrom simetrične inicijalne nesavršenosti funkcionirala je lošije od one $s$ jezgrom protu-simetrične početne nesavršenosti u kompresiji. Nadalje, manji početni progib vanjskih ograničavajućih elemenata i amplitude razmaka rezultira manjom dodirnom silom te spojnica može stoga učinkovitije funkcionirati.

Ključne riječi: distribucija dodirne sile; početna (inicijalan) nesavršenost); razmak; razrađeni finitni element; spojnica ograničenog izvijanja

\section{Introduction}

Buckling-restrained brace (BRB) is an energy dissipating member which yields under compression without overall buckling. It consists of a steel core member bearing the entire axial load, external restraining members preventing the core member from buckling, and the gap or unbounded material that fills the space between the core and external restraining members [1-3]. According to the material and components of external restraining member, BRBs are often categorized as reinforced concrete BRBs [4, 5], steel and concrete composite BRBs [2, 6, 7], and assembled BRBs [8-13]. The behaviour of assembled BRBs has recently been widely studied for their advantages, including the features of light weight, easy transportation to construction sites for assembly. It is usually assembled with several external restraining members connected by high-strength structural bolts, as shown in Fig. 1(a).

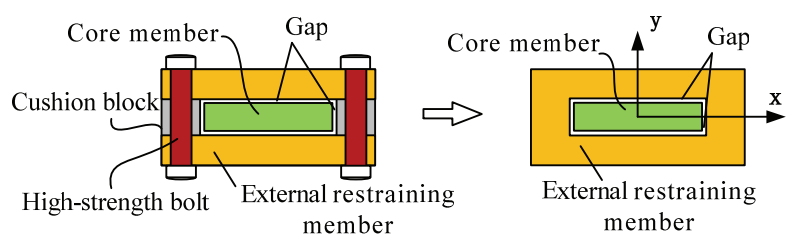

(a) Assembled BRB

(b) Integrated BRB

Figure 1 Composition diagram of BRB
To date, many investigations have been conducted on the seismic performance of BRBs [2, 14-21]. Unfortunately, few works attempted to evaluate the evolution of core member deformations and contact force distribution between core and external components, which in fact, is key to understanding the mechanical, also energy dissipation mechanism of BRBs. Once the contact force distribution and amplitude are determined, the stress level of the external restraining member, as well as the bolt stress and bolt layout of the assembled BRB can be easily obtained.

Currently, considerable researches on the contact relationship mainly focus on theoretical derivation, experimental research and numerical analysis. In the aspect of theoretical derivation, a series of assumptions were made. These assumptions mainly focus on specific buckling waveform and the corresponding contact force distribution, etc. However, no FE analysis was found to verify the rationality of these assumptions. Zhao et al. [22] assumed that two-point-contact occurs at the end of the core and external restraining members, but Guo et al. [8] deemed that the lateral deformation of the core and external restraining members were the same, and the contact force distribution appeared as a sine distribution pattern. Experimental research mainly aimed at investigating the overall performance of BRBs $[5,10,19$, 23], but did not consider the variation of the core waveform and the contact force. Although the core 
buckling waveform was investigated in some articles [14, 16], only the contact status and contact position of the core member were deduced from the variation of the external restraining member strain. Moreover, the accuracy of this assessment was not verified. Some scholars $[10,13]$ investigated the overall performance of BRBs by using the FE model. But further research on core waveform evolution and the influence of initial imperfection are absent.

Therefore, this work aims to evaluate the deformation evolution of the core buckling waveform under axial forces by using refined finite element analysis of a simplified BRB model, and examine the contact force distribution between the core and external restraining members. In addition, the object-oriented programming language Python is applied in the ABAQUS parameter analysis, and the influences of several factors on the waveform variation of core member, core contact force distribution, and overall performance of BRB are considered in the analysis, including the initial imperfection forms of core member, the initial imperfection amplitude of external restraining member, as well as the gap.

\section{Finite Element Model}

This study mainly focuses on contact force distribution between the core and external restraining members. Thus, the assembled BRB shown in Fig. 1(a) can be replaced by an external integrated BRB for simplification, as shown in Fig. 1(b). In the simplified model shown in Fig. 2, the external restraining member is modelled as a square tube, and the core member is a single steel plate. Two wing plates are welded at the end of the core member to provide sufficient stiffness to the unrestrained region. A gap is set between the core and external restraining members to form an unbounded layer. A groove is designed on the external restraining member to facilitate the axial compression deformation of the core member. Slot stiffening plates are used to strengthen the local external restraining member around the groove.

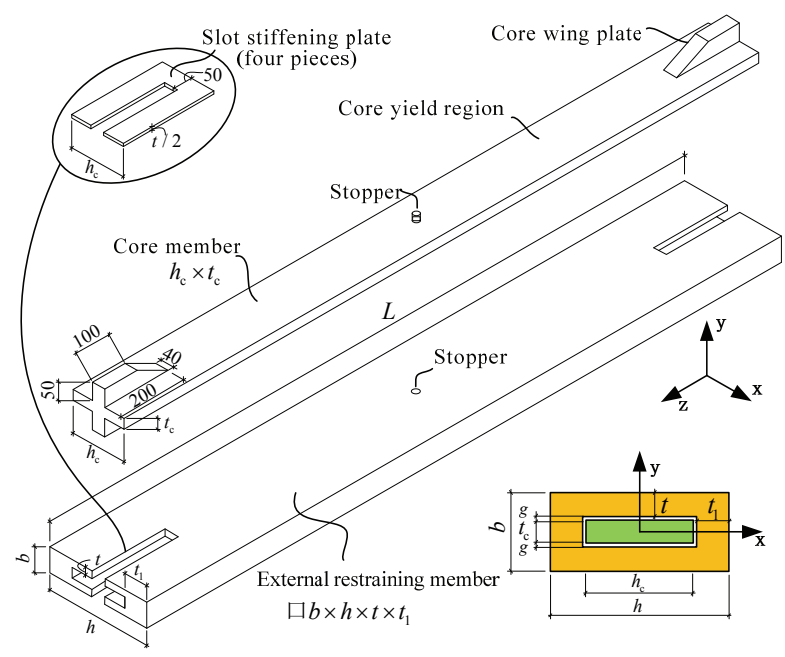

Figure 2 Composition diagram of simplified BRB (Unit mm)

The finite element software ABAQUS [24] is employed to analyse the simplified BRB model, as shown in Fig. 3. Solid element is used to model core member, external restraining member and stopper where the 8-node linear brick element with reduced integration namely $\mathrm{C} 3 \mathrm{D} 8 \mathrm{R}$ is selected. Contact pair is established on the contact surface between the core and external restraining members as well as the stopper and the hole at the midspan of external restraining member. The friction between contact pair is not considered. Tie constraint is set to the stopper and core member. The core plate is assumed to have yield strength of $235 \mathrm{MPa}$, with a hardening modulus of $2 \%$ elasticity modulus in plastic stage. For external restraining member and slot stiffening plate, the yield strength of $345 \mathrm{MPa}$ is adopted, and all members have an elasticity modulus of $206 \mathrm{GPa}$.

To set the brace boundary conditions conveniently, a cruciform rigid end plate is arranged at the end of the core member, and its property is set as ideal elasticity material. Tie constraint is also set between the end plate and core member. Hinged ends are applied to the central axis of both end plates, and axial displacement is restrained to simulate axial compression condition. This study deals with core member buckling, which rotates around the $\mathrm{x}$ axis. Thus, the deformation of the core member along the $\mathrm{x}$ axis is restrained. In addition, the core and external restraining members are divided into 100 parts, which brings convenience to the moment obtaining using free body cut in post processing.

The dimension of core member is set as $160 \mathrm{~mm}$ wide and $30 \mathrm{~mm}$ thick, and the external member is a square tube with dimensions of $72 \times 304 \times 20 \times 70 \mathrm{~mm}$ (Fig. 2). The dimension of wing plates at the core end is $200 \times 50 \times 40$ $\mathrm{mm}$. The lengths of the core and external restraining members are both $2 \mathrm{~m}$. All the detailed dimension information on core member, external restraining member, core stiffening wing plate, slot stiffening plate are listed in Fig. 2.

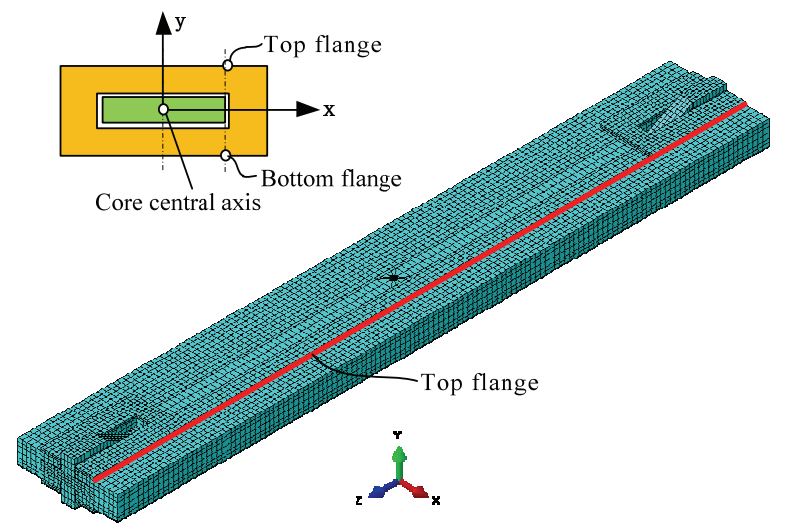

Figure 3 Diagram of FE model of BRB and observation point

To observe the performance of BRB conveniently, the mid-span node of core member is set as an observation point to investigate the lateral displacement variation during the loading process. Meanwhile, the core central axis, top flange, bottom flange shown in Fig. 3, are also observed.

The damping factor of contact control is set as 1E-4 to enhance numerical convergence. A comparative analysis indicated that the results can meet the requirements of convergence and computational accuracy 
with a relatively short run time. The full Newton-Raphson method [24] is used for solution in this study, where the maximum and minimum increment sizes of the analysis step are set as 0,005 and $1 \mathrm{E}-10$, respectively.

\section{Influence of the core initial imperfection form}

Initial geometric imperfection of inner core member is usually induced by manufacturing error. Fig.4 shows two common core initial imperfection forms, i.e. the symmetric single-wave mode and the anti-symmetric double-wave mode. This section focuses on the influences of two typical core initial imperfection forms on the core waveform variation and BRB overall performance, as shown in Fig. 4.

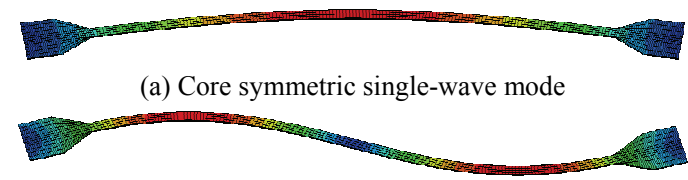

b) Core anti-symmetric double-wave mode

Figure 4 Core initial imperfection forms of BRB

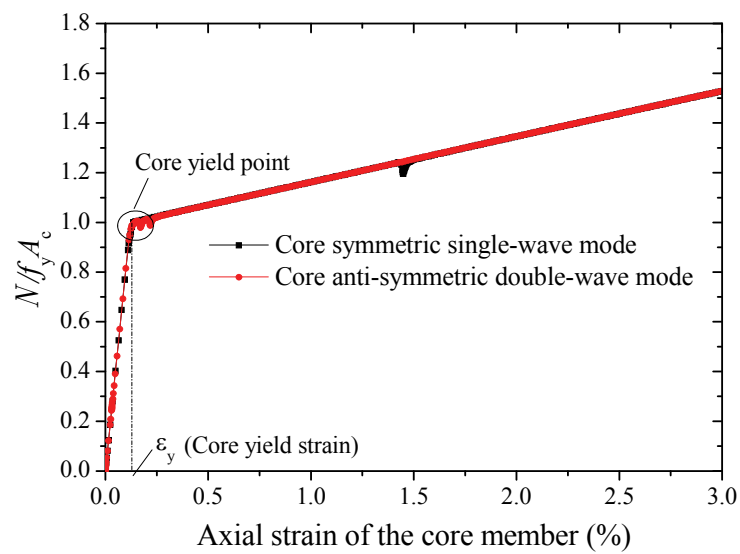

(a) Core axial strain-axial force curve

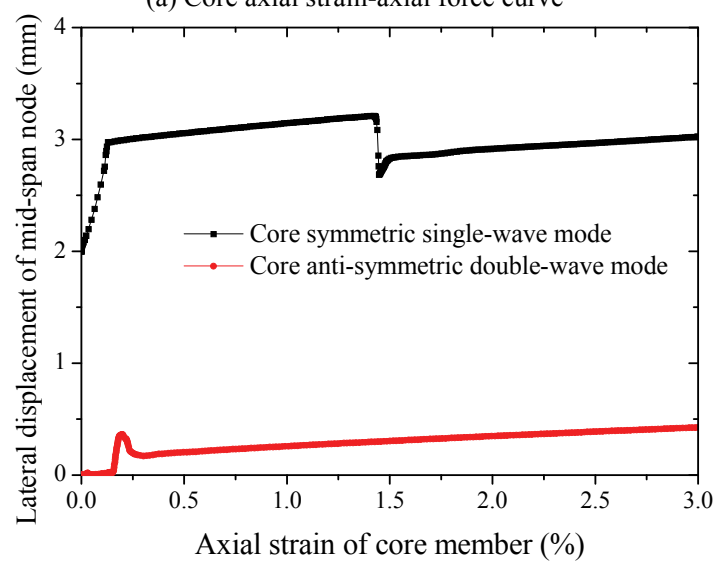

(b) Core axial strain-lateral displacement curve

Figure 5 Core axial strain-relevant parameters curve

The external restraining member of a BRB is assumed to be impeccable, which means no overall initial imperfection. The gap between both sides of the core and external restraining members is $1 \mathrm{~mm}$. The core symmetric single-wave initial imperfection with amplitude of $2 \mathrm{~mm}$ and the anti-symmetric double-wave initial imperfection with amplitude of $1 \mathrm{~mm}$ are applied to the core member for it to contact with the external restraining member in the early loading stage and avoid the problem of non-convergence caused by the rigid body displacement of the external restraining member. The $\mathrm{BRB}$ restraining ratio, namely the ratio of the Euler buckling load of BRB to the yield load of core member, is set as 3,98, which guarantees stable bearing capacity and minimal lateral deformation of the BRB.

Fig. 5 shows the relationship between the core axial strain and relevant parameters. Each BRB model possesses a stable bearing capacity during the whole static loading process, as shown in Fig. 5(a). Fig. 5(b) presents the development of core mid-span node lateral displacement with increasing axial strain. The fluctuation of curve in this figure indicates the waveform variation of core member. For instance, the core waveform of the $\mathrm{BRB}$ with core single-wave imperfection transforms from the former single-wave form into triple-wave form when core axial strain is $1,45 \%$. The abscissa value in the figure represents nominal axial strain, namely the ratio between core axial displacement and nominal length of core yield region. This value slightly differs from the real plastic strain of core member because the real length of core yield region changes with increasing axial load. The out-of-plane deformation of core member along the length that corresponds to $3 \%$ axial strain is shown in Fig. 6.

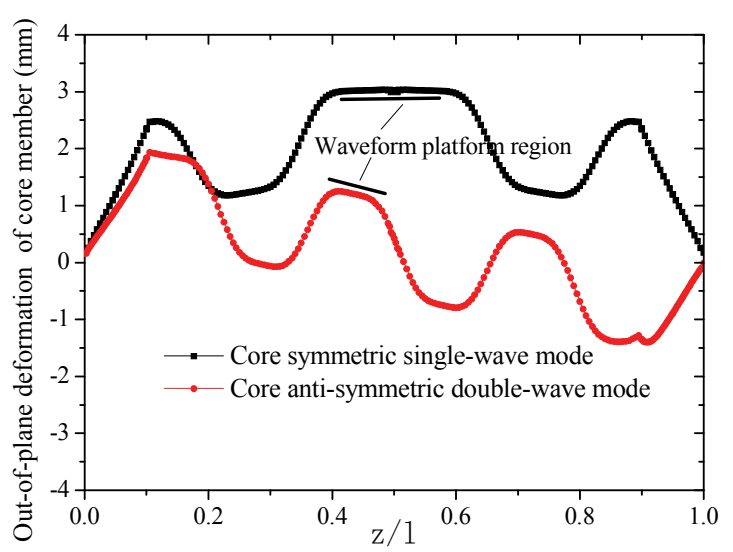

Figure 6 Out-of-plane deformation of core member along the length (3 $\%$ strain)

Fig. 7 shows the deformation evolution of inner core member with the increase of core axial strain. Core member with larger slenderness has single-wave initial bending (Fig. 7(0)). It will gradually form a three-pointcontact with the external restraining member under axial force (two-point-contact at the end and one-point-contact at mid-span). In such case, the external restraining member will formally enter into the working status and mainly under bending status, Fig. 7(a). With increasing axial load, the one-point-contact at core mid-span will change into two-point-contact and contacting region gradually diffuses toward both ends, Fig. 7(b), until it gets close to the core stiffening wing plate, as shown in Fig. 7(c). Thereafter, the contact force at core stiffening region will decrease, and a contact force will appear at core midspan region to balance vertical force. In such case, the reverse bending moment will occur and cause the variation of the core waveform, as shown in Fig. 7(d) and Fig. 7(e). Once the waveform development completes, the core mid-span region will form the two-point-contact 
condition again, Fig. 7(f). If, however, core member is incapable of forming a higher-order buckling waveform because of length limitation, all the one-point-contacts area will gradually transform to two-point-contact status, Fig. 7(g). For observation convenience, the gap between the core and external member is exaggerated in the figure.

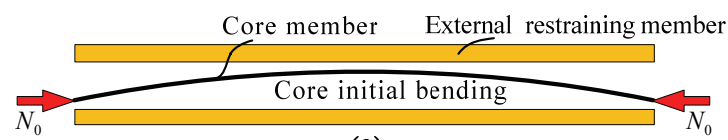

(0)
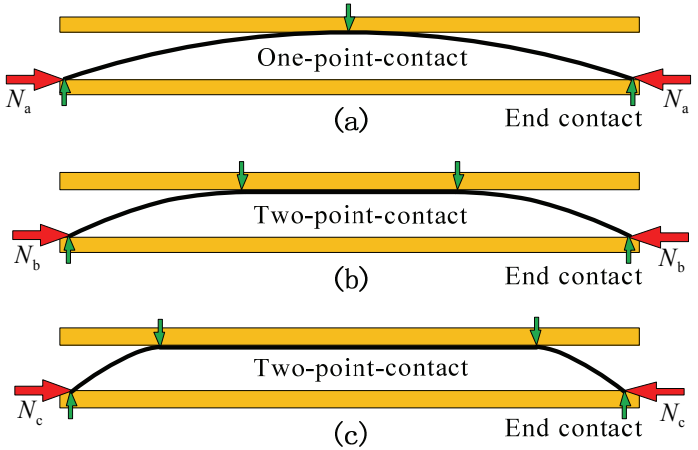

Reverse bending moment

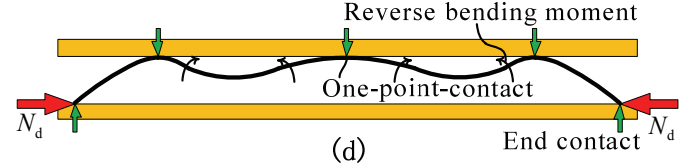

Reverse bending moment

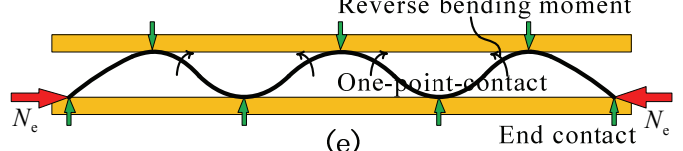

(e)

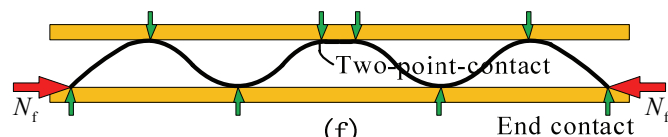

(f)

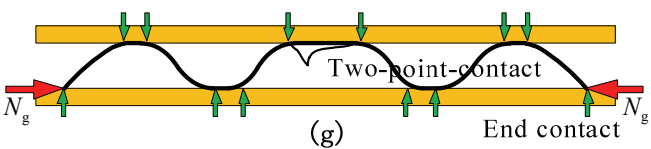

Figure 7 Core multi-wave development process of the BRB with core single-wave imperfection

Fig. 8, Fig. 9 and Fig. 10 respectively present the core out-of-plane deformation diagram, the core bending moment distribution diagram, and the core contact force distribution diagram under typical strain levels during the BRB loading process mentioned in Fig. 7. The multiwave variation of core member is observed to be caused by reverse bending moment, which is correlated to the contact force distribution pattern. This moment is induced by the core axial force together with the contact force. Besides, the bending moment at the core contact region is mainly zero, and the point of inflection will be formed in the middle of core member waveform, where the core bending moment is also zero. This result can be a reference for deducing the core contact force equation in the future.

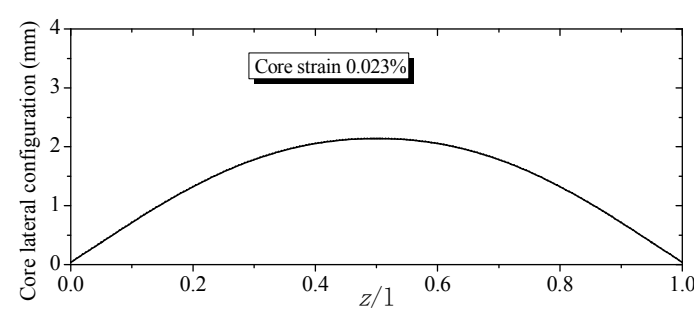

(a) $N_{\mathrm{a}} / N_{\mathrm{y}}=0.186\left(\varepsilon / \varepsilon_{\mathrm{y}}=0.20\right)$

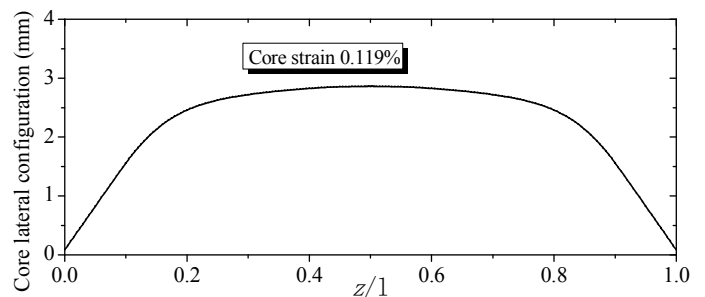

(b) $N_{\mathrm{b}} / N_{\mathrm{y}}=0.943\left(\varepsilon / \varepsilon_{\mathrm{y}}=1.04\right)$

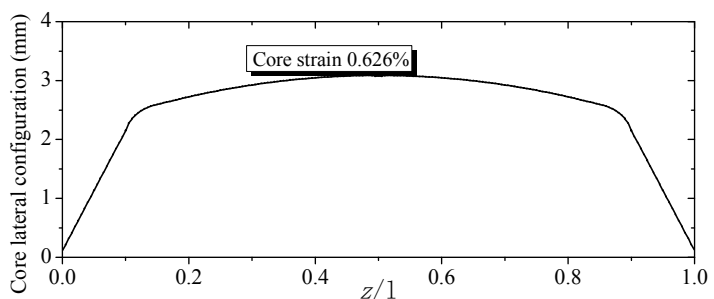

(c) $N_{\mathrm{c}} / N_{\mathrm{y}}=1.094\left(\varepsilon / \varepsilon_{\mathrm{y}}=5.49\right)$

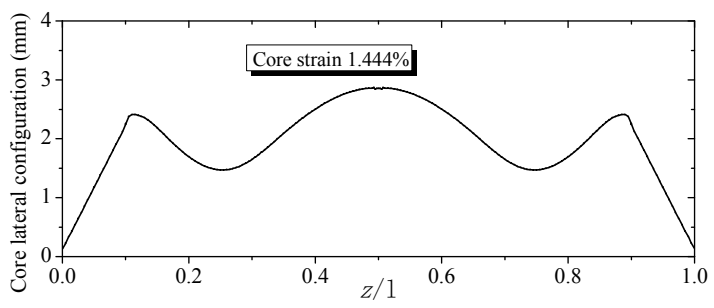

(d) $N_{\mathrm{d}} / N_{\mathrm{y}}=1.212 \quad\left(\varepsilon / \varepsilon_{\mathrm{y}}=12.67\right)$

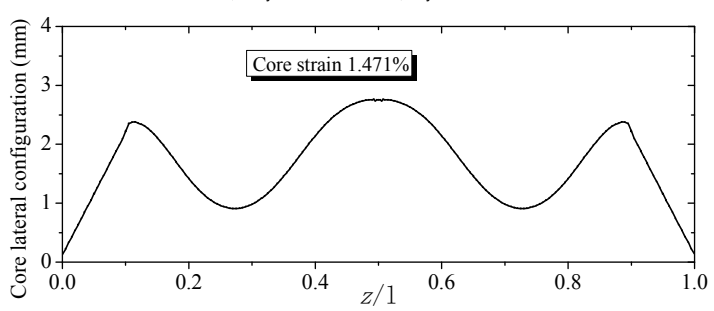

(e) $N_{\mathrm{e}} / N_{\mathrm{y}}=1.241\left(\varepsilon / \varepsilon_{\mathrm{y}}=12.90\right)$

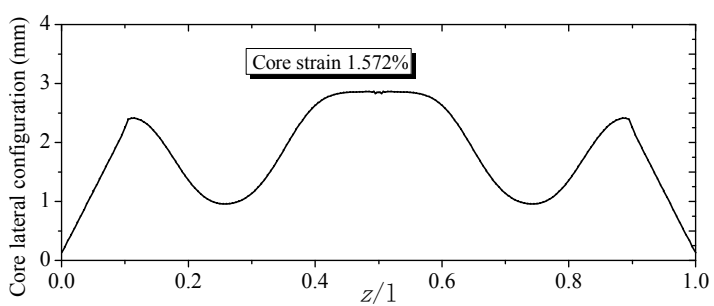

(f) $N_{\mathrm{f}} / N_{\mathrm{y}}=1.266\left(\varepsilon / \varepsilon_{\mathrm{y}}=13.79\right)$

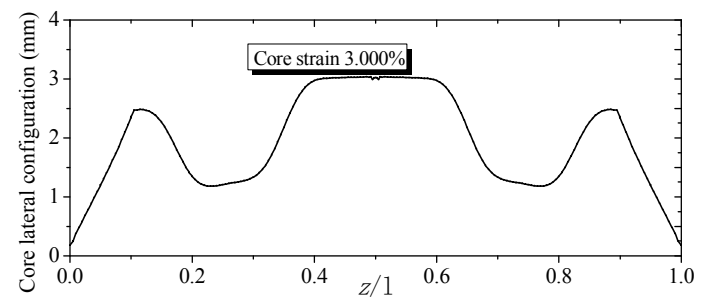

(g) $N_{\mathrm{g}} / N_{\mathrm{y}}=1.528\left(\varepsilon / \varepsilon_{\mathrm{y}}=26.32\right)$

Figure 8 Core out-of-plane deformation diagram 


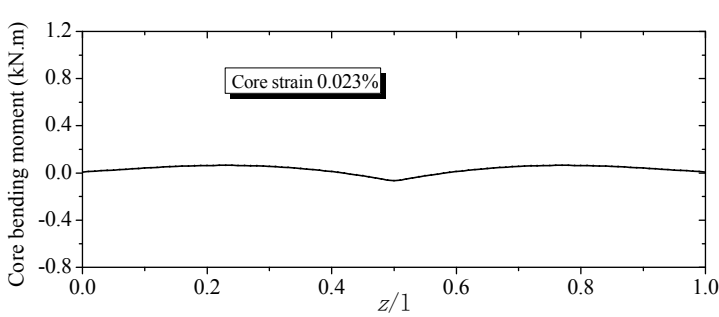

(a) $N_{\mathrm{a}} / N_{\mathrm{y}}=0.186\left(\varepsilon / \varepsilon_{\mathrm{y}}=0.20\right)$

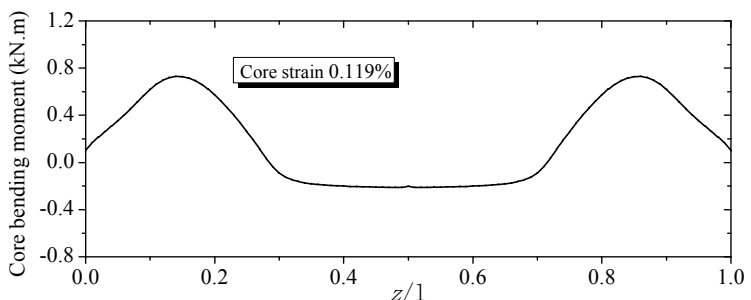

(b) $N_{\mathrm{b}} / N_{\mathrm{y}}=0.943\left(\varepsilon / \varepsilon_{\mathrm{y}}=1.04\right)$

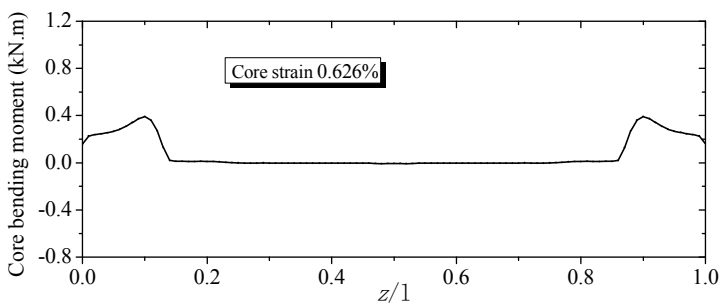

(c) $N_{\mathrm{c}} / N_{\mathrm{y}}=1.094\left(\varepsilon / \varepsilon_{\mathrm{y}}=5.49\right)$

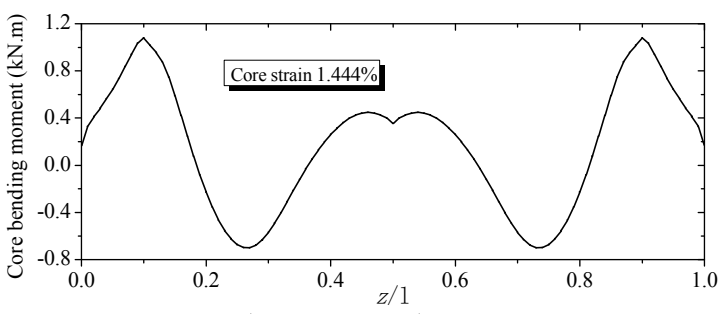

(d) $N_{\mathrm{d}} / N_{\mathrm{y}}=1.212 \quad\left(\varepsilon / \varepsilon_{\mathrm{y}}=12.67\right)$

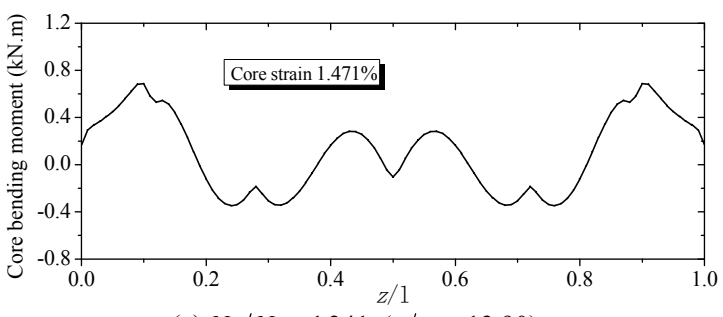

(e) $N_{\mathrm{e}} / N_{\mathrm{y}}=1.241 \quad\left(\varepsilon / \varepsilon_{\mathrm{y}}=12.90\right)$

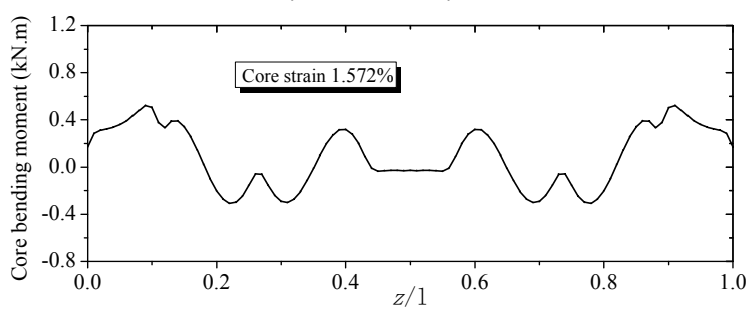

(f) $N_{\mathrm{f}} / N_{\mathrm{y}}=1.266\left(\varepsilon / \varepsilon_{\mathrm{y}}=13.79\right)$

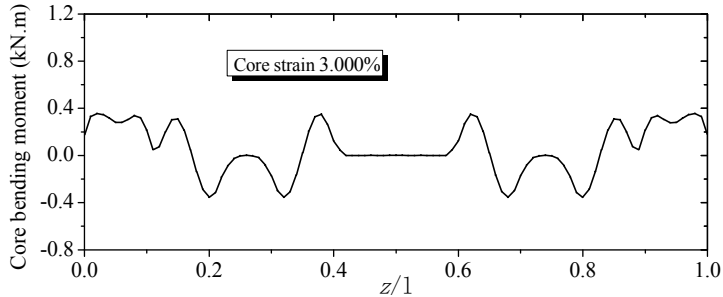

(g) $N_{\mathrm{g}} / N_{\mathrm{y}}=1.528\left(\varepsilon / \varepsilon_{\mathrm{y}}=26.32\right)$

Figure 9 Core bending moment distribution diagram
Additionally, with the increase of axial strain, the core contact force also increases. On the other hand, when the waveform varies, the contact force distribution form significantly changes. Instead of increasing, the contact force decreases, as shown in Fig. 10(c) and Fig. 10(d). Therefore, as regards the overall performance, the variation of core waveform enables the $\mathrm{BRB}$ to perform more effectively. This condition will be discussed according to several strain levels of the external restraining member in the following sections.

Fig. 11 shows the stress distribution diagrams of external restraining member under five different core strain levels. This figure shows the development of core member waveform as axial strain increases. It indicates that the stress of external restraining member exhibits the following evolution: increasing (single-wave status) $\rightarrow$ decreasing (turning from single-wave into multi-wave status) $\rightarrow$ increasing again (multi-wave status). Compared with two strain levels, core strains of $1,301 \%$ and 1,472 $\%$ illustrate that although core axial force increases, the overall stress level of external member presents an obvious decreasing trend with the variation of core waveform. In such case, the overall stress of BRB is more favourable, although the local stress of external member, in which waveform varies, also increases. Considering that local stress is usually less important than overall stress, the overall stress status of a core single-wave BRB is worse than that of the core multi-wave BRB under the same axial force.

Similarly, the core region at left side of the core antisymmetric double-wave imperfection BRB is considered, as shown in Fig. 12(0). The core member will contact with external member at the zigzag position under axial force and thus cause a slight contact force exerted on the external member, which compels the external restraining member to rotate until the end of core member contact with it. Then BRB enters into the working status, as shown in Fig. 12(a). With the increase of axial strain, the one-point-contact on the left region of core member gradually turns into two one-point-contacts (Fig. 12(b)). The reverse bending moment of this core region gradually increases until the core region develops into three onepoint-contacts (Fig. 12(c)). After the waveform variation completes, one-point-contact will develop into two-pointcontact with increasing axial strain again (Fig. 12(d)).

Fig. 13 presents the core contact force distribution diagram when core axial strain is $3 \%$. For the BRB with core multi-wave buckling, core contact forces applied to external member near the mid-span are basically the same, and the lengths of waveforms are also similar. However, the length of core waveform platform region (Fig. 6) is closely related to core initial imperfection forms and core axial strain, which cannot be reflected in the theoretical derivation.

From the aforementioned figures, it is found out that the BRB with symmetric initial imperfection performs symmetrically, whereas the BRB with anti-symmetric initial imperfection performs anti-symmetric. Numerical analysis results also indicate that the BRB with antisymmetric initial imperfection possesses smaller core outof-plane deformation and external member stress level than that of BRB with symmetric initial imperfection, so anti-symmetric initial imperfection is beneficial for BRB 
to bear axial force. This finding indicates that the BRB with core symmetric imperfection is usually unfavourable when compared with the BRB with anti-symmetric imperfection, which is in common with the conclusion of Zhao et al. [22]. Considering that the real initial imperfection form of core member is usually

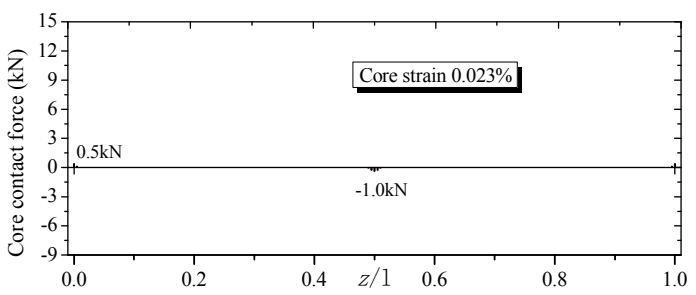

(a) $N_{\mathrm{a}} / N_{\mathrm{y}}=0.186\left(\varepsilon / \varepsilon_{\mathrm{y}}=0.20\right)$

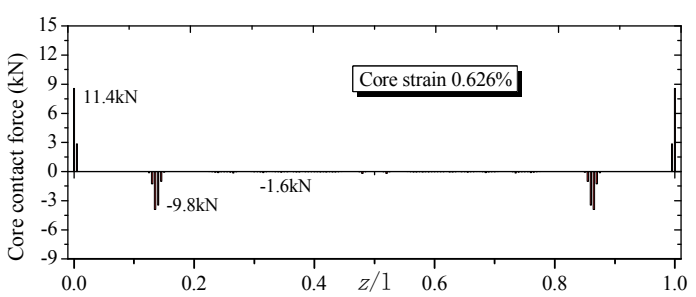

(c) $N_{\mathrm{c}} / N_{\mathrm{y}}=1.094\left(\varepsilon / \varepsilon_{\mathrm{y}}=5.49\right)$

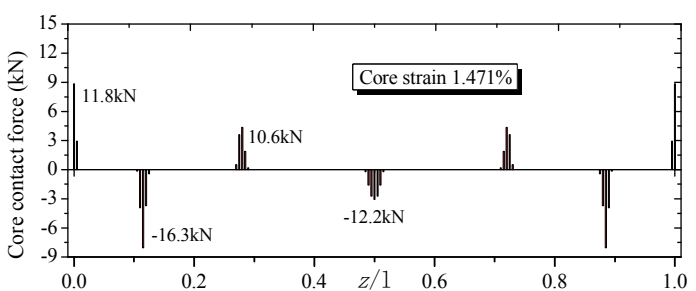

(e) $N_{\mathrm{e}} / N_{\mathrm{y}}=1.241\left(\varepsilon / \varepsilon_{\mathrm{y}}=12.90\right)$ unpredictable, the favourable influence caused by antisymmetric initial imperfection will not be considered in the subsequent research. On the contrary, the core member will be assumed to have a single-wave initial imperfection distribution form.

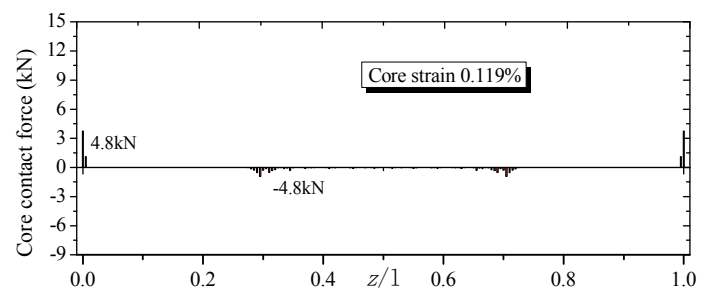

(b) $N_{\mathrm{b}} / N_{\mathrm{y}}=0.943\left(\varepsilon / \varepsilon_{\mathrm{y}}=1.04\right)$

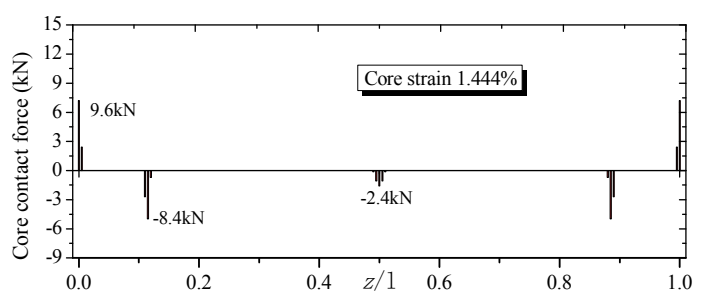

(d) $N_{\mathrm{d}} / N_{\mathrm{y}}=1.212 \quad\left(\varepsilon / \varepsilon_{\mathrm{y}}=12.67\right)$

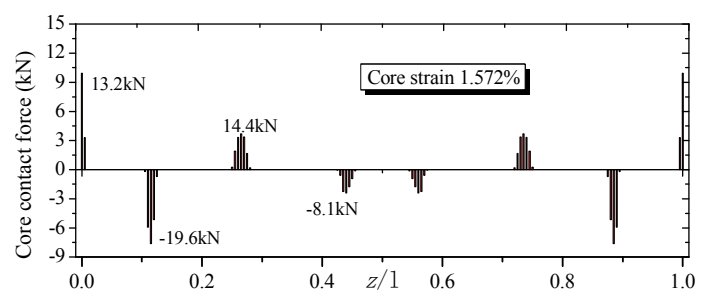

(f) $N_{\mathrm{f}} / N_{\mathrm{y}}=1.266\left(\varepsilon / \varepsilon_{\mathrm{y}}=13.79\right)$

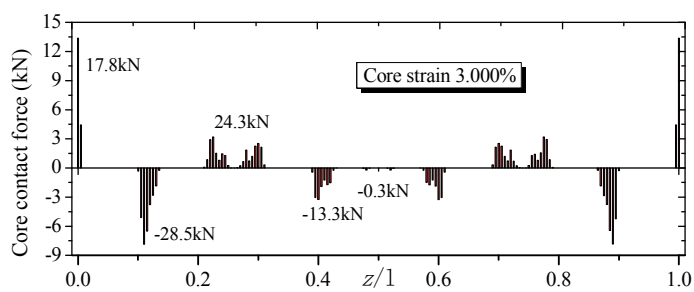

(g) $N_{\mathrm{g}} / N_{\mathrm{y}}=1.528\left(\varepsilon / \varepsilon_{\mathrm{y}}=26.32\right)$

Figure 10 Core contact force distribution diagram of the BRB with core single -wave imperfection

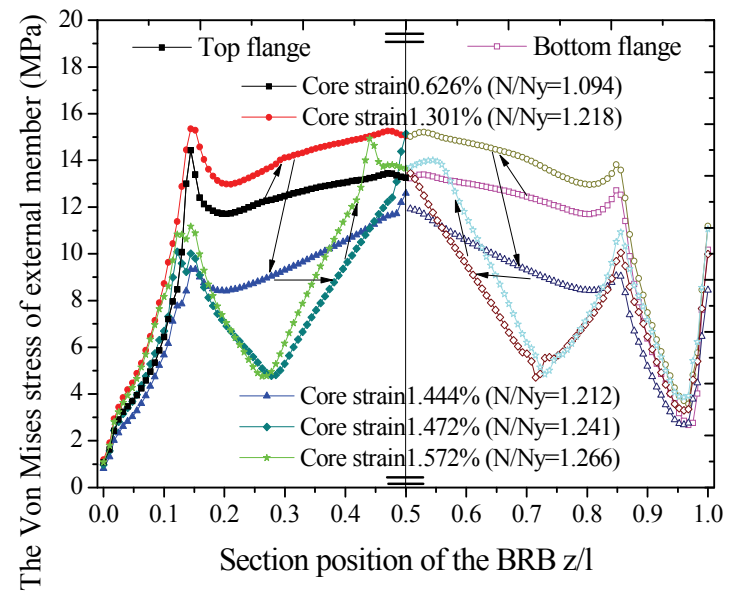

Figure 11 External restraining member stress distribution diagram under each strain

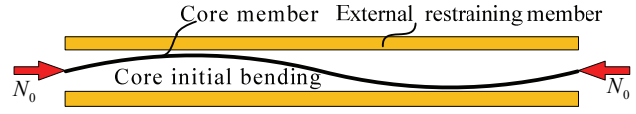

(0)
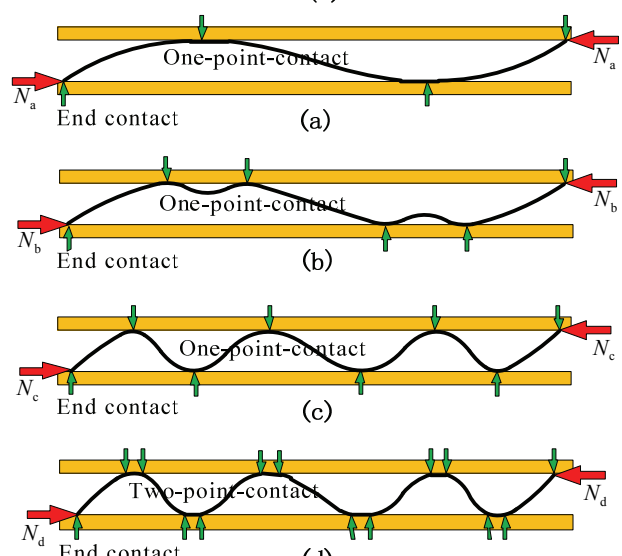

(d)

Figure 12 Core multi-wave development process of the BRB with core double-wave imperfection 


\section{Influence of BRB Initial Imperfection Amplitude}

The previous section discussed core initial imperfection forms. This section focuses on the influence of initial imperfection amplitude on BRB performance. The BRB with core symmetric single-wave initial imperfection is discussed in the following section.

\subsection{Compositions of BRB imperfection}

The imperfection of BRB mainly includes external restraining member imperfection and core member imperfection. Core imperfection has complicated compositions that are closely related to the initial working status of BRB. Thus, the following discussion primarily focuses on the working status of BRB.

The initial imperfection of the external restraining member and core member is assumed to be sinusoidal, and imperfection amplitude is $\delta_{0}$ and $\delta_{1}$, respectively. The gap between the core and external restraining members is $2 \mathrm{~g}$, where $\mathrm{g}$ represents the gap between core member and one side of external restraining member, as shown in Fig. 14(a). When bearing certain axial load, core member will undergo lateral bending moment because of its slenderness and eventually contact with the external member, resulting in the latter being pushed to move. After core member contact with external member at the end, the former will formally enter into the working status, as shown in Fig. 14(b). Assuming imperfection amplitude of core member in the initial working status is $\delta_{2}$. Obviously, $\delta_{2}$ is mainly composed of the external member initial imperfection $\delta_{0}$ and the gap ( $2 \mathrm{~g}$ ) between the core and external restraining members, which is unrelated to the core initial imperfection $\delta_{1}$.

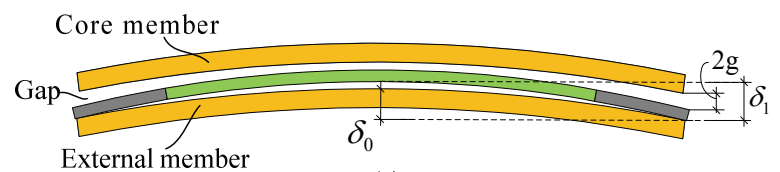

(a)

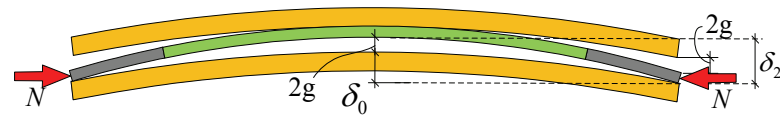

(b)

Figure 14 Initial working status of BRB

Geometric imperfection with external initial imperfection amplitude should be first applied to the BRB model when performing FE analysis to obtain the original contact between the core and external members at the initial loading stage, as well as to avoid the nonconvergence caused by the rigid body displacement of external member. The local imperfection amplitude applied to core member is determined by core initial imperfection forms and gap amplitude. Considering that core member is assumed to have only a single-wave initial imperfection, the local imperfection amplitude applied to core member is the gap $(2 \mathrm{~g})$ between the core and external restraining members.

\subsection{Influence of external initial imperfection amplitude $\delta_{0}$}

The influence of initial imperfection amplitude of external restraining member on $\mathrm{BRB}$ performance is discussed in this section. The external initial imperfection amplitude changes, whereas the gap is presumed to remain the same.

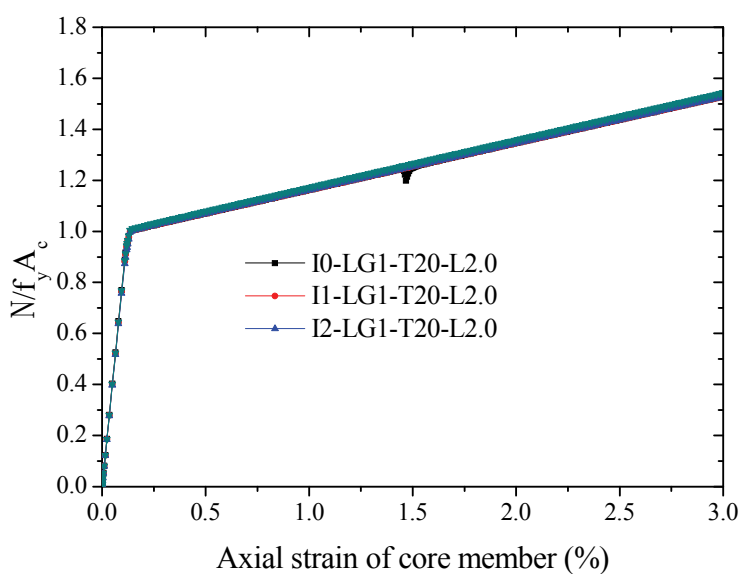

(a) Core axial strain-axial force curve

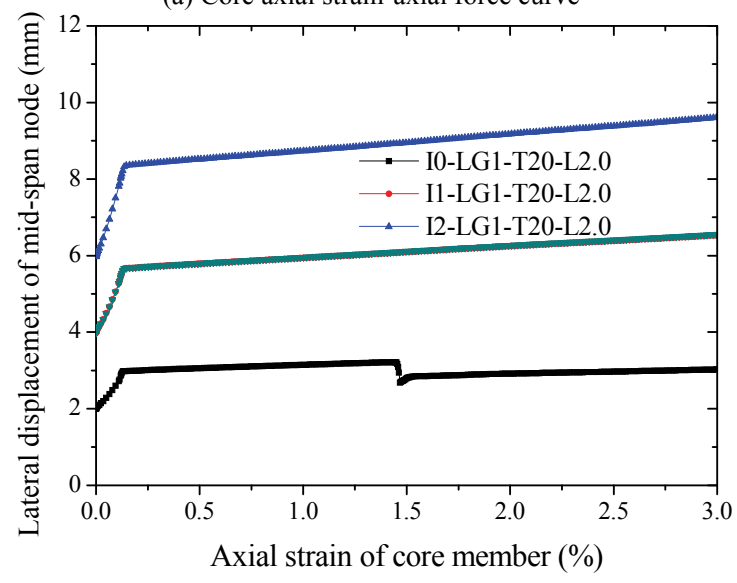

(b) Core axial strain-lateral displacement curve

Figure 15 Core axial strain-relevant parameters curve

Three external initial imperfection amplitude cases are investigated. BRB model is denoted by Ix-LGx-Tx$\mathrm{Lx}$, where $\mathrm{I} 0$ denotes that the external restraining member of BRB has no initial imperfection, I1 denotes that the external restraining member has $\mathrm{L} / 1000$ overall initial imperfection, and $\mathrm{I} 2$ denotes that the external restraining member has L/500 overall initial imperfection. LGx denotes the local initial imperfection amplitude, and $x$ is the gap between core member and one side of external member. Tx denotes that the thickness of top and bottom flanges of external member is $\mathrm{x} \mathrm{mm}$. Lx denotes the length of BRB. For instance, L2.0 indicates that the length of both the core and external restraining members $\mathrm{L}$ is 2,0 $\mathrm{m}$.

Numerical analysis results show that the BRB models have stable load-displacement curve, as shown in Fig. 15(a). Fig. 15(b) shows the lateral displacement curve of core member mid-span node. The start point of this curve shows the model difference, which results from external initial imperfection. The figure also shows the variations when core waveform varies. For instance, model I2-LG1 shows that the waveform varies when core strain is $1,2 \%$. The core waveform that corresponds to $3 \%$ axial strain is 
shown in Fig. 16.

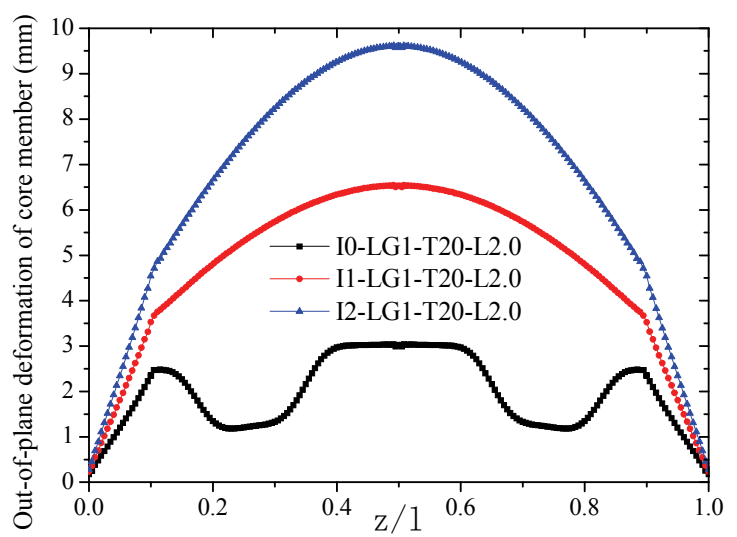

Figure 16 Out-of-plane deformation of core member along the length (3 $\%$ strain)

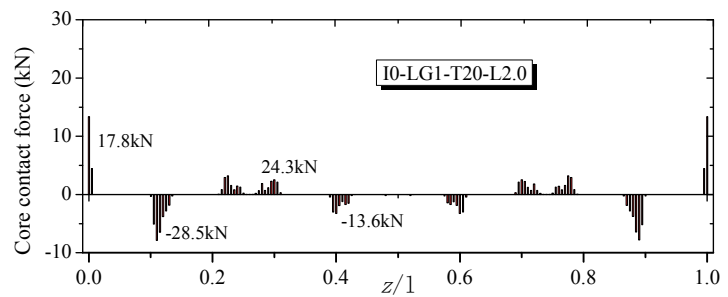

(a) I0-LG1-T20-L2.0 model

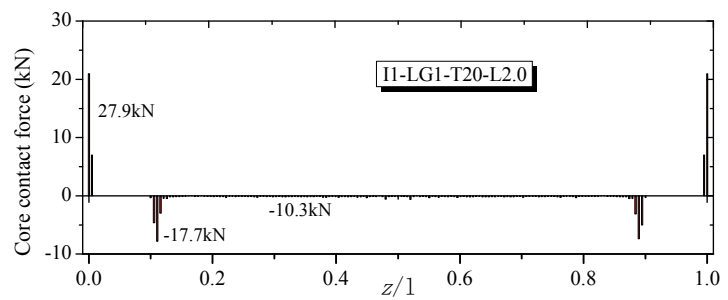

(b) I1-LG1-T20-L2.0 model

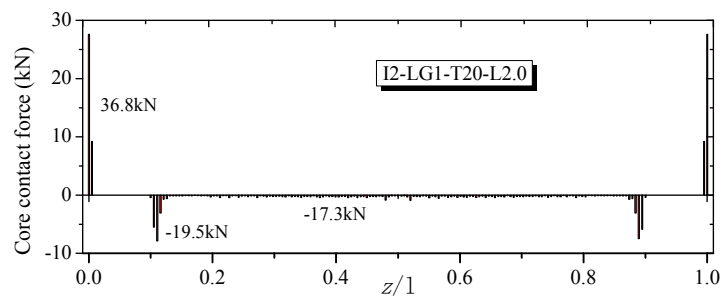

(c) I2-LG1-T20-L2.0 model

Figure 17 Core contact force distribution of models (3\% strain)

The out-of-plane deformation of core member (Fig. 16) and core contact force distribution (Fig. 17) show that larger initial imperfection of external restraining member will bring larger core contact force on external restraining member and out-of-plane deformation of core member. This condition consequently results in greater external restraining member stress. While the BRB with smaller external imperfection results in a mild lateral deformation and smaller core contact force, because of which the core member is more likely to exhibit multi-wave buckling. According to the external restraining member stress distribution diagram (Fig. 18), the core with multi-wave buckling is found to reduce the overall stress level of external restraining member effectively, which is beneficial to BRB performance.

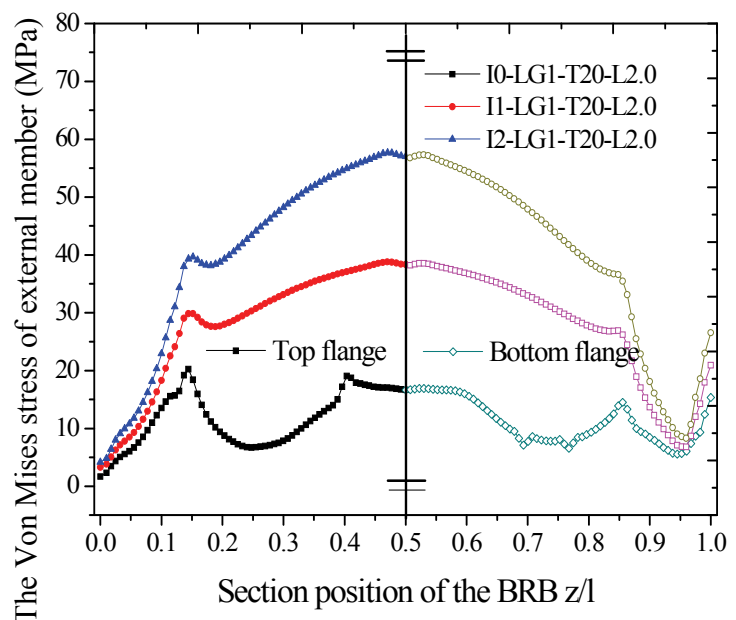

Figure 18 External restraining member stress distribution diagram of models (3\% strain)

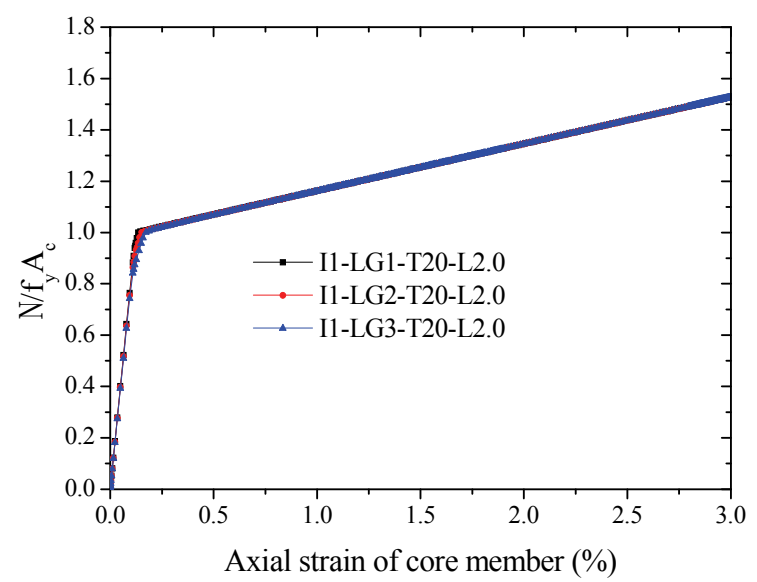

(a) Core axial strain-axial force curve

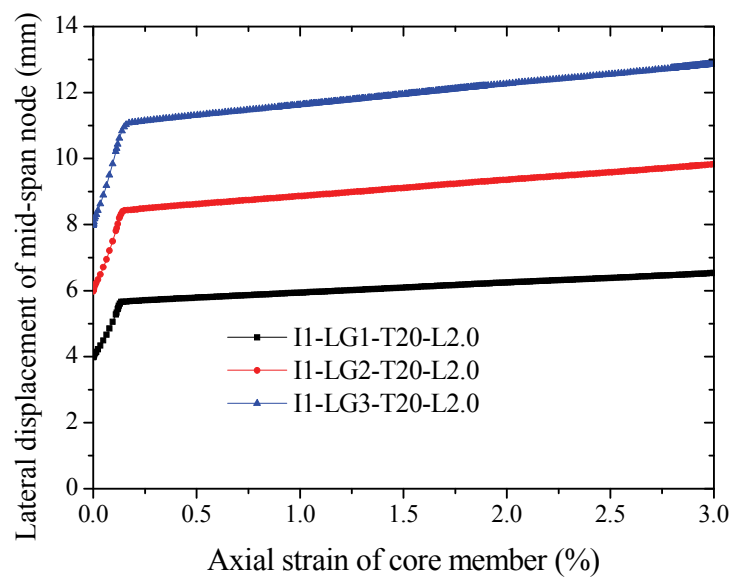

(b) Core axial strain-lateral displacement curve

Figure 19 Core axial strain-relevant parameters curve

\subsection{Influence of gap $(2 \mathrm{~g})$ between the core and external restraining members}

The gap directly influences core imperfection amplitude, so in this section, three BRB models are established to investigate the gap influences on BRB performance. The overall initial imperfection amplitude of L/1000 is applied to these models. The analysis results indicate that all BRB models possess stable bearing capacity. However, the existing large gap causes large out-of-plane deformation of core member during the 
initial loading stage. With increasing axial strain, the adverse effect of the gap on lateral displacement of core member becomes more significant.

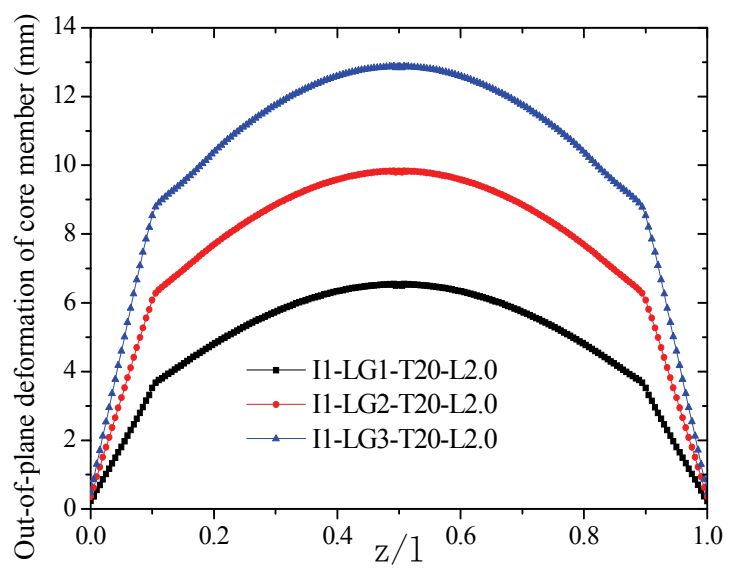

Figure 20 Out-of-plane deformation of core member along the length (3 $\%$ strain)

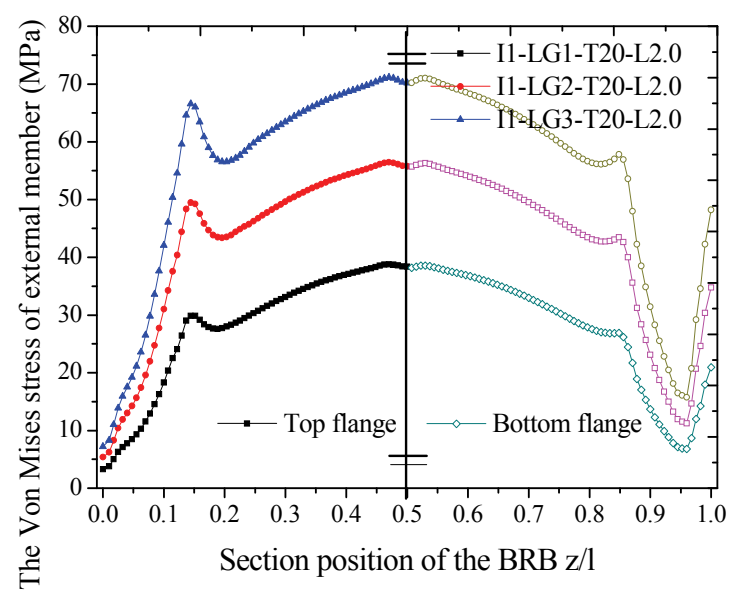

Figure 21 External restraining member stress distribution diagram of models (3\% strain)

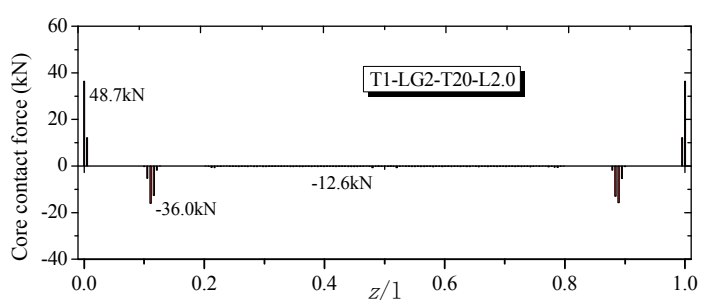

(a) I1-LG2-T20-L2.0 model

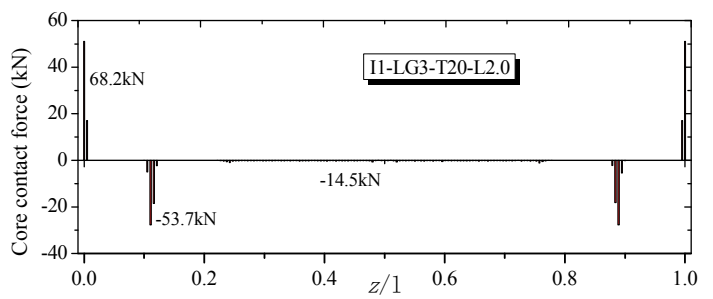

(b) I1-LG3-T20-L2.0 model

Figure 22 Core contact force distribution of models ( $3 \%$ strain)

Fig. 20 and Fig. 21 depict the out-of-plane deformation of core member and the stress distribution of external restraining member when core axial strain is $3 \%$. Fig. 22 shows the contact force distribution of BRB models. Comparison of these figures shows that an increasing gap has worse influence on BRB performance, inducing larger out-of-plane deformation, larger contact force and external restraining member stress. Thus, the thinner unbounded material or smaller gap is recommended.

From the core contact force distribution, it is found out that when core waveform remains the same, contact force gradually increases linearly with the increase of the gap. This result can also be a reference for deducing the core contact force equation.

It should be noted that the dimension of external member and the friction coefficient between the core and external member can also influence the BRB performance, which will be discussed in follow-up studies.

\section{Conclusions}

This study conducted a refined FE analysis by using a simplified BRB model to investigate the evolution of the core buckling mode with increasing axial compression and to evaluate core contact force distribution along the length. The influences of some parameters on BRB overall performance are analysed, including core initial imperfection form, initial imperfection amplitude of external member, and the gap between the core and external restraining members. The following conclusions are obtained:

1) The evolution of the buckling modes mainly results from the reverse bending moment acting on core member. This moment is generated by core axial force and contact force provided by the external restraining member.

2) Core contact force generally increases with increasing axial strain. However, the core contact force distribution changes when core waveform varies. Then the contact force will decrease rather than increase. Meanwhile the overall stress of external restraining member decreases, but its local stress increases.

3) Compared with the core anti-symmetric initial imperfection, the $\mathrm{BRB}$ with core symmetric initial imperfection results in larger lateral deformation and stress level of external restraining member. To make conservative design, the BRB with core symmetric singlewave initial imperfection should always be considered.

4) When core member contacts with external restraining member at the end, the BRB formally enters into the working status. In such case, the core member imperfection consists of the external restraining member initial imperfection $\delta_{0}$ and the gap $(2 \mathrm{~g})$ between the core and external restraining members, and has nothing to do with the core initial imperfection amplitude $\delta_{1}$.

5) Larger initial imperfection of external restraining member and gap may result in larger lateral deformation, core contact force and external member stress level, which is unfavourable to BRB overall performance. So the initial imperfection amplitude should be controlled.

\section{Acknowledgements}

This research is supported by the National Natural Science Foundation of China (51178243). 


\section{References}

[1] Qiang, X. Status of the art of buckling-restrained braces in Asia. // J Constr Steel Res. 61, (2005). Pp. 727-748. DOl: 10.1016/j.jcsr.2004.11.005

[2] Black, C. J.; Makris, N.; Aiken, I. D. Component testing, seismic evaluation and characterization of bucklingrestrained braces. // J Struct Eng ASCE. 130, 6(2004), pp. 880-894. DOI: 10.1061/(ASCE)0733-9445(2004)130:6(880)

[3] Fujimoto, M.; Wada, A.; Saeki, E.; Hitomi, Y.; Watanabe, A. Properties of Brace Encase in Buckiling-Restraining Concrete and Steel Tube. $/ / 9^{\text {th }}$ WCEE. Vol. IV, (1988), pp. 719-723.

[4] Inoue, K.; Sawaizumi, S.; Higashibata, Y. Stiffening requirements for unbonded braces encased in concrete panels. // J StructEng ASCE. 127, 6(2001), pp. 712-719. DOI: 10.1061/(ASCE)0733-9445(2001)127:6(712)

[5] Yukun, D.; Yaochun, Z.; Junxian, Z. Tests of hysteretic behavior for unbonded steel plate brace encased in reinforced concrete panel. // J Construct Steel Res. 65, 5(2009), pp. 1160-1170. DOI: 10.1016/j.jcsr.2008.11.003

[6] Nagao, T.; Mikuriya, K.; Matsumoto, Y. et al. An experimental study on the elasto-plastic behavior of unbonded composite bracing (part 1-4). // Summaries of Technical Papers of Annual Meeting of the Architectural Institute of Japan. Structural Engineering Section II. Tokyo, Japan, 1988, pp. 1329-1336. (in Japanese).

[7] Koetaka, Y.; Narihara, H.; Tsujita, O. Experimental study on buckling restrained braces. // Proceeding of Sixth Pacific Structural Steel Conference. Beijing, China, 2001, pp. 1517.

[8] Yanlin, Guo; Leixin, Jiang. Behavior and application of buckling-restrained braces assembled with section steels. // Building Struct. 40, 1(2010), pp. 30-37. (in Chinese).

[9] Zhao, J.; Wu, B.; Ou, J. A novel type of angle steel buckling-restrained brace: Cyclic behavior and failure mechanism. // Earthq Eng Struct D. 40, 10(2011), pp. 10831102. DOI: 10.1002/eqe.1071

[10] Chou, C.; Chen, S. Subassemblage tests and finite element analyses of sandwiched buckling-restrained braces. // Eng Struct. 32, 8(2010), pp. 2108-2121. DOl: 10.1016/j.engstruct.2010.03.014

[11] Wang, C.; Usami, T.; Funayama, J. et al. Low-cycle fatigue testing of extruded aluminium alloy buckling-restrained braces. // Eng Struct. 46, (2013), pp. 294-301. DOI: 10.1016/j.engstruct.2012.07.016

[12] Usami, T.; Wang, C. L.; Funayama, J. Developing highperformance aluminum alloy buckling-restrained braces based on series of low-cycle fatigue tests. // Earthq Eng Struct D. 41, 4(2012), pp. 643-661. DOI: 10.1002/eqe.1149

[13] Hoveidae, N.; Rafezy, B. Overall buckling behavior of allsteel buckling restrained braces. // J Construct Steel Res. 79, (2012), pp. 151-158. DOI: 10.1016/j.jcsr.2012.07.022

[14] Takeuchi, T.; Hajjar, J. F.; Matsui, R. et al. Effect of local buckling core plate restraint in buckling restrained braces. // Eng Struct. 44, (2012), pp. 304-311. DOI: 10.1016/j.engstruct.2012.05.026

[15] Genna, F.; Gelfi, P. Analysis of the Lateral Thrust in Bolted Steel Buckling-Restrained Braces. I: Experimental and Numerical Results. // J Struct Eng ASCE. 138, 10(2011), pp. 1231-1243. DOI: 10.1061/(ASCE)ST.1943-541X.0000558

[16] Takeuchi, T.; Hajjar, J. F.; Matsui, R. et al. Local buckling restraint condition for core plates in buckling restrained braces. // J Construct Steel Res. 66, 2(2010), pp. 139-149. DOI: 10.1016/j.jcsr.2009.09.002

[17] Eryasar, M. E.; Topkaya, C. An experimental study on steel-encased buckling-restrained brace hysteretic dampers. // Earthq Eng Struct D. 39, 5(2010), pp. 561-581.

[18] Fahnestock, L. A.; Ricles, J. M.; Sause, R. Experimental evaluation of a large-scale buckling-restrained braced frame. // J Struct Eng ASCE. 133, 9(2007), pp. 1205-1214. DOI: 10.1061/(ASCE)0733-9445(2007)133:9(1205)

[19] Tremblay, R.; Bolduc, P.; Neville, R. et al. Seismic testing and performance of buckling-restrained bracing systems. // Can J Civil Eng. 33, 2(2006), pp. 183-198. DOI: 10.1139/105103

[20] Iwata, M.; Murai, M. Buckling-restrained brace using steel mortar planks; performance evaluation as a hysteretic damper. // Earthq Eng Struct D. 35, 14(2006), pp 18071818. DOI: $10.1002 /$ eqe.608

[21] Chen, C. C.; Chen, S. Y.; Liaw, J. J. Application of low yield strength steel on controlled plastification ductile concentrically braced frames. // Can J Civil Eng. 28, 5(2001), pp. 823-836. DOI: 10.1139/101-044

[22] Zhao, J.; Wu, B.; Ou, J. Flexural Demand on PinConnected Buckling-Restrained Braces and Design Recommendations. // J Struct Eng ASCE. 138, 11(2011), pp. 1398-1415. DOI: 10.1061/(ASCE)ST.1943-541X.0000549

[23] Ju, Y. K.; Kim, M.; Kim, J. et al. Component tests of buckling-restrained braces with unconstrained length. // Eng Struct. 31, 2(2009), pp. 507-516. DOI: 10.1016/j.engstruct.2008.09.014

[24] ABAQUS. Standard user's manual version 6.10. Pawtucket, RI: Hibbitt, Karlsson \& Sorensen, Inc., 2010.

\section{Authors' addresses}

Ziqin Jiang

College of Architecture and Civil Engineering, Beijing University of Technology,

Beijing, 100124, China

E-mail: jzqbj2010@163.com

Yanlin Guo

Department of Civil Engineering,

Tsinghua University,

Beijing, 100084, China

E-mail: gyl@mail.tsinghua.edu.cn

Hang Chen

Department of Civil Engineering ,

Tsinghua University

Beijing, 100084, China

E-mail: chenhang_1002@126.com

\section{Xuqiao Zhang}

Department of Civil Engineering,

Tsinghua University,

Beijing, 100084, Chin

E-mail: zhangxq89@gmail.com 